\title{
Effect of Calcium Carbonate Whisker and Fly Ash on Mechanical Properties of Cement Mortar under High Temperatures
}

\author{
Li Wang, ${ }^{1}$ Hongliang Zhang $\mathbb{D}^{1}{ }^{1}$ Bendong Zhao, ${ }^{2}$ and Yang Gao ${ }^{1}$ \\ ${ }^{1}$ Key Laboratory for Special Area Highway Engineering of Ministry of Education, Chang'an University, Xi'an, Shaanxi, China \\ ${ }^{2}$ CCCC First Highway Consultants Co. Ltd., Xi'an, Shaanxi, China \\ Correspondence should be addressed to Hongliang Zhang; zhliang0105@163.com
}

Received 8 February 2019; Revised 9 April 2019; Accepted 18 April 2019; Published 7 May 2019

Guest Editor: Rishi Gupta

Copyright $(2019$ Li Wang et al. This is an open access article distributed under the Creative Commons Attribution License, which permits unrestricted use, distribution, and reproduction in any medium, provided the original work is properly cited.

Calcium carbonate $\left(\mathrm{CaCO}_{3}\right)$ whisker, as a new type of microfibrous material, has been extensively used in the reinforcement of cementitious materials. However, the combined effect of $\mathrm{CaCO}_{3}$ whisker and fly ash on mechanical properties of cementitious materials under high temperatures was still unknown. In this study, the coupling effect of $\mathrm{CaCO}_{3}$ whisker, and fly ash on mechanical properties of the cement was investigated. Two sets of cement mortars were fabricated, including $\mathrm{CaCO}_{3}$ whiskerbased mortar which contained $0 \mathrm{wt} . \%, 5 \mathrm{wt} . \%, 10 \mathrm{wt} . \%, 15 \mathrm{wt} . \%$, and $20 \mathrm{wt} . \% \mathrm{CaCO}_{3}$ whisker as cement substitution and $\mathrm{CaCO}_{3}$ whisker-based fly ash mortar which contained $30 \mathrm{wt} . \%$ fly ash in addition to 0 wt. $\%, 5$ wt. $\%, 10$ wt. $\%, 15$ wt. $\%$, and 20 wt. $\%$ CaCO whisker as cement substitution. Mass loss, compressive strength, and flexural strength of these two sets of specimens before and after being subjected to high temperatures of $200^{\circ} \mathrm{C}, 400^{\circ} \mathrm{C}, 600^{\circ} \mathrm{C}, 800^{\circ} \mathrm{C}$, and $1000^{\circ} \mathrm{C}$ were measured. Based on the results of the aforementioned tests, load-deflection test was performed on the specimen which exhibited the superior performance to further study its mechanical behavior after exposure to high temperatures. Moreover, microstructural analysis, such as mercury intrusion porosimetry (MIP) and scanning electron microscopy (SEM), was conducted to reveal the damage mechanism of high temperature and to illustrate the combined effect of $\mathrm{CaCO}_{3}$ whisker and fly ash on high-temperature resistance of the cement. Results showed that fly ash could improve the high-temperature performance of $\mathrm{CaCO}_{3}$ whisker-based mortar before $600^{\circ} \mathrm{C}$ and limit the loss of strength after $600^{\circ} \mathrm{C}$.

\section{Introduction}

Fire is one of the fatal threats which seriously affect human life, property security, and economic development in the world. Concrete, as a widely used key material in the construction of infrastructural facilities, is noncombustible and performs well when exposed to high temperatures because the components of it, such as cement and aggregates, are chemically inert. However, the physical and chemical deteriorations of cementitious materials due to moisture loss and decomposition of hydrated products at high temperatures may result in the generation of cracks and the loss to mechanical strengths of concrete, finally lead to the structural damage [1]. Therefore, it is crucial to investigate the mechanical performance of concrete at elevated temperatures and enhance the mechanical properties of concrete, which can also provide references for engineers to select concrete of good fire resistance.

As is well known, concrete is a brittle material which has low flexural strength, and in practice, a variety of fibrous materials, such as steel, carbon, polymer, and natural fibers, are often employed to enhance its toughness [2-5]. The whisker is a new type of microfibrous, single-crystal material which has tiny diameter and large aspect ratio, and therefore, it possesses both the characteristics of fillers and fibers. In addition, the atomic arrangement of the whisker is highly ordered, so theoretically its strength is close to that of intact crystal. And above all, whiskers often have excellent thermostability with high decomposition temperature around $800^{\circ} \mathrm{C}$ which makes them a suitable reinforcement for composite materials not only to enhance 
mechanical properties but also to improve hightemperature resistance performance. Whiskers can be categorized as organic and inorganic whiskers, and organic whisker such as cellulosic whisker is frequently used for reinforcing the polymer materials $[6,7]$. With respect to inorganic whisker, calcium carbonate whisker [8-12], calcium sulphate whisker [13], zinc oxide whisker [14], silicon carbide whisker [15], and potassium titanate whisker [16] are commonly used, and among which, $\mathrm{CaCO}_{3}$ whisker has the most extensive application in the reinforcement of cementitious materials. Previous studies have shown that $\mathrm{CaCO}_{3}$ whisker has the capacity to improve the mechanical strength and enhance the flexural toughness of cementitious materials. Cao et al. conducted a series of researches on the application of $\mathrm{CaCO}_{3}$ whisker in cementitious materials, and they found that, with the incorporation of $\mathrm{CaCO}_{3}$ whisker, mechanical properties of cement pastes were improved before the temperature was up to $600^{\circ} \mathrm{C}$ while a deteriorated phenomenon was observed at $600-1000^{\circ} \mathrm{C}[8,9]$. They also discovered that, at ambient temperature, $\mathrm{CaCO}_{3}$ whisker significantly improved the flexural strength of cement mortar, and the optimum dosage was $10 \%$ [10]. Moreover, they indicated that the rheological properties of mortars containing $\mathrm{CaCO}_{3}$ whisker complied with the Bingham model and with the whisker content of $1.5 \%$, and mortars exhibited the uniform distribution [11]. Yang et al. reported that $\mathrm{CaCO}_{3}$ whisker with the addition of $10 \%$ could remarkably enhance the tensile strength of cement paste, and the constitutive relationship of the stress-strain curve of $\mathrm{CaCO}_{3}$ whisker-reinforced cement pastes and toughening mechanism of $\mathrm{CaCO}_{3}$ whisker were illustrated as well [12]. On the other hand, the microsize of $\mathrm{CaCO}_{3}$ whisker enables the combined use of it with various large-sized fibers in order to achieve the multiscale cracking resistance of cementitious materials [17-21].

Moreover, as global warming continues, environmental protection should be taken into consideration prior to the construction of concrete structures. However, during the manufacturing of cement, environmental problem associated with huge emissions of greenhouse gases, mainly carbon dioxide $\left(\mathrm{CO}_{2}\right)$, has raised concern for sustainable development, based on the fact that the production of every tonne of ordinary Portland cement (OPC) releases an equivalent amount of $\mathrm{CO}_{2}$ into the atmosphere [22]. In addition, with the development of urbanization, the accompanying high demand for cement will make the environmental problem increasingly severe, and measures should be taken to reduce the energy consumption and curb the emission of $\mathrm{CO}_{2}$ during the fabrication of cement. In consideration of sustainability and energy conservation, one of the effective measures to reduce the consumption of cement is to replace part of the cement with supplementary cementitious materials (SCMs), such as fly ash, silica fume, and granulated blast furnace slag, and other waste materials [23].

Fly ash, as one of the most important SCMs, is a byproduct of coal power stations and therefore using it as cement substitution not only reduce the production of cement but also provide an efficient method for disposal of waste material compared with other conventional disposal methods. Silicon dioxide $\left(\mathrm{SiO}_{2}\right)$ and aluminium oxide $\left(\mathrm{Al}_{2} \mathrm{O}_{3}\right)$, as main chemical compositions of fly ash, can react with calcium hydroxide $(\mathrm{CH})$ produced during cement hydration to form calcium silicate hydrate $(\mathrm{CSH})$ and calcium aluminate hydrate $(\mathrm{CAH})$, thereby densifying the paste and achieving higher strength and better durability, which is known as pozzolanic effect of fly ash. Generally, the cement replacement by fly ash is limited to be around $15 \%-30 \%$ by mass of the total binding material. Previous studies have pointed out the superiority of fly ash when it is moderately incorporated into cementitious materials as cement replacement. In particular, the mechanical strength of fly ash concrete after exposure to high temperatures is still comparatively advantageous, although the overall strength of concrete decreases with the increase in maximum temperature. The study of Ibrahim et al. has demonstrated that, after exposure to high temperatures of up to $700^{\circ} \mathrm{C}$, mechanical properties of mortars were enhanced when $25 \%$ of cement was replaced by fly ash [24]. Tanyildizi and Coskun reported that, under high temperatures of up to $800^{\circ} \mathrm{C}$, mechanical strengths of concrete were improved through substituting up to $30 \%$ of cement with fly ash [1]. Soleimanzadeh and Othuman found that the flexural strength of foamed concrete containing 30\% FA was higher than the ordinary concrete after exposure to high temperatures of up to $600^{\circ} \mathrm{C}[25]$.

To the best of our knowledge, the combined effect of $\mathrm{CaCO}_{3}$ whisker and fly ash on mechanical properties of cementitious materials after exposure to elevated temperatures has not been reported. Better understanding this knowledge could extend the application of $\mathrm{CaCO}_{3}$ whisker and facilitate the utilization of fly ash, thereby lowering the amount of other expensive fibers, reducing the overall cost of concrete projects, and promoting the sustainable development. In the current study, systematic experiments, including mass loss test, compressive strength test, flexural strength test, and load-deflection curve test, were carried out to study the influence of $\mathrm{CaCO}_{3}$ whisker and fly ash on properties of cement mortars before and after exposure to high temperatures of $200^{\circ} \mathrm{C}, 400^{\circ} \mathrm{C}, 600^{\circ} \mathrm{C}, 800^{\circ} \mathrm{C}$, and $1000^{\circ} \mathrm{C}$. Meanwhile, the effect of $\mathrm{CaCO}_{3}$ whisker on the high-temperature performance of cement mortars was also examined as a reference to see whether fly ash could have a positive influence on the high-temperature performance of $\mathrm{CaCO}_{3}$ whisker-based cement mortar and thus promoting the sustainable development. Furthermore, the deterioration mechanism of high temperatures and the interaction mechanism of $\mathrm{CaCO}_{3}$ whisker and fly ash with the cement were explored by MIP and SEM.

\section{Materials and Experiments}

2.1. Raw Materials. Raw materials used in this study include cement, fly ash, $\mathrm{CaCO}_{3}$ whisker, and natural river sand. Cement was OPC 42.5 that met the requirements of ASTM C150 specification [26]. Fly ash was class F fly ash that met the requirements of ASTM C618 specification [27]. $\mathrm{CaCO}_{3}$ whisker that has a high tensile strength of 3-6 GPa and high 
elastic modulus of 410-710 GPa was used in this study. The diameter and aspect ratio of it was in the range of 5-10 $\mu \mathrm{m}$ and 10-30, respectively, as shown in Figure 1. The chemical compositions of the cement, the fly ash, and the whisker, provided by suppliers, are presented in Table 1. The sand used in this study was natural river sand with a fineness modulus of 2.7. In order to maintain a favorable workability, polycarboxylic-type water-reducing agent that met the requirements of ASTM C494-type F specification [28] was also used in this study.

2.2. Specimen Preparation. In order to investigate the mechanical properties and microstructural mechanism of cement mortars containing $\mathrm{CaCO}_{3}$ whisker and fly ash, different types of specimens were prepared. Cement, natural river sand, and water were used in all the mortar mixtures, along with $\mathrm{CaCO}_{3}$ whisker and fly ash in specific mixtures. To be exact, cement mortars were classified into two sets, which were $\mathrm{CaCO}_{3}$ whisker-based mortar and $\mathrm{CaCO}_{3}$ whisker-based fly ash mortar. The first set was $\mathrm{CaCO}_{3}$ whisker-based mortar which contained OPC and different contents of $\mathrm{CaCO}_{3}$ whisker (e.g., 0 wt.\%, 5 wt.\%, 10 wt.\%, $15 \mathrm{wt} . \%$, and $20 \mathrm{wt} . \%$ ) as the binder, while the second set was $\mathrm{CaCO}_{3}$ whisker-based fly ash mortar which was fabricated with OPC and $30 \mathrm{wt} . \%$ fly ash as a fixed substitution of cement in addition to $0 \mathrm{wt} . \%, 5 \mathrm{wt} . \%, 10 \mathrm{wt} . \%, 15 \mathrm{wt} . \%$, and 20 wt.\% $\mathrm{CaCO}_{3}$ whisker. Therefore, a total number of ten mortar mixtures were designed in this study. It should be noted that, for all the mixtures, a constant water-to-binder ratio of 0.4 , binder-to-sand ratio of $1: 2.75$, and a total cementitious material content of $500 \mathrm{~kg} / \mathrm{m}^{3}$ were used. Details of the mix proportions are listed in Table 2.

With respect to specimen fabrication, raw materials, such as cement, $\mathrm{CaCO}_{3}$ whisker, fly ash, and sand, according to the corresponding mix proportions, were mixed together for $3 \mathrm{~min}$ by an electrically driven mixer before adding the mixing water. Then, $70 \%$ of the mixing water was added to the mixture and mixed for another $3 \mathrm{~min}$. Thereafter, the water-reducing agent together with the rest of the mixing water was added, and the mixture was mixed for $1 \mathrm{~min}$ to ensure the homogeneity and uniformity of it. The mixture was subsequently placed into stainless steel molds and vibrated on a vibration machine for $2 \mathrm{~min}$ to achieve a desirable compactness. And after $24 \mathrm{~h}$ of curing, the molded mortar specimens were removed from the molds and left to continue curing for $27 \mathrm{~d}$ under a temperature of $20^{\circ} \mathrm{C}$ and a relative humidity of $95 \%$ until the testing day. Cubic specimens of $50 \times 50 \times 50 \mathrm{~mm}$ were prepared for the test of compressive strength and prismatic specimens of $40 \times 40 \times$ $160 \mathrm{~mm}$ were prepared for the tests of flexural strength and load-deflection curve.

2.3. Heating Regimes. High temperatures of $200^{\circ} \mathrm{C}, 400^{\circ} \mathrm{C}$, $600^{\circ} \mathrm{C}, 800^{\circ} \mathrm{C}$, and $1000^{\circ} \mathrm{C}$ were selected in this investigation, and these high temperatures were achieved through using an electrically heated furnace which covered a temperature range of $20-1000^{\circ} \mathrm{C}$ and a constant heating rate of $10^{\circ} \mathrm{C} / \mathrm{min}$. When the prescribed temperature was reached, the temperature of the furnace was kept constantly for $1 \mathrm{~h}$ so as to ensure the thermal steady state [29]. Thereafter, the specimens were cooled down naturally to room temperature and were subsequently subjected to the associated tests including mass loss test and mechanical tests so as to evaluate their high-temperature resistance capacity.

2.4. Mass Loss. The evaporation of moisture and decomposition of hydration products of cement paste under high temperature will lead to the mass change of cement mortar, which is an important indicator to deteriorations of cement mortar after exposure to high temperature. Therefore, the mass of mortar specimens before and after exposure to various high temperatures was recorded prior to the mechanical property test to calculate the mass loss during the heating process. It should be noted that, before exposure to high temperatures, specimens were put into a drying oven for $24 \mathrm{~h}$ at $100^{\circ} \mathrm{C}$.

2.5. Mechanical Properties. The compressive strength of cubic specimens before and after exposure to different high temperatures was obtained through operating a hydraulic testing machine according to ASTM C109 [30]. The flexural behavior of prismatic specimens before and after exposure to different high temperatures was also evaluated in accordance with ASTM C348 [31] and ASTM C1609 [32]. Triplicate specimens were tested for each parameter, and the average values were recorded.

In this investigation, the mortar specimen that exhibited the optimal high-temperature resistance based on the results of the mechanical experiments was selected as the optimal specimen for further microstructural analysis, together with the ordinary specimen $\mathrm{C} 0$ which contained only OPC as the binder for comparison.

2.6. Pore Size Distribution. There is a general agreement that the mechanical properties of a material are closely related to its microstructure [33]. Therefore, it is an effective method to evaluate the degradations of specimens after being subjected to high temperatures through pore structure analysis. In accordance with ISO 15901-1 [34], mercury intrusion porosimetry (MIP) was employed to assess the porosity and pore size distribution of the ordinary specimen and the optimal specimen before and after exposure to varying high temperatures (e.g., $200^{\circ} \mathrm{C}, 400^{\circ} \mathrm{C}, 600^{\circ} \mathrm{C}, 800^{\circ} \mathrm{C}$, and $1000^{\circ} \mathrm{C}$ ).

2.7. SEM Analysis. The microscopic images of the ordinary specimen and the optimal specimen before and after exposure to different high temperatures were also acquired by scanning electron microscopy (SEM) analysis. The specimens should be coated with gold to be conductive prior to the test.

\section{Results and Discussion}

3.1. Mass Loss. When exposed to various high temperatures, the mass of a substance will be altered due to different 


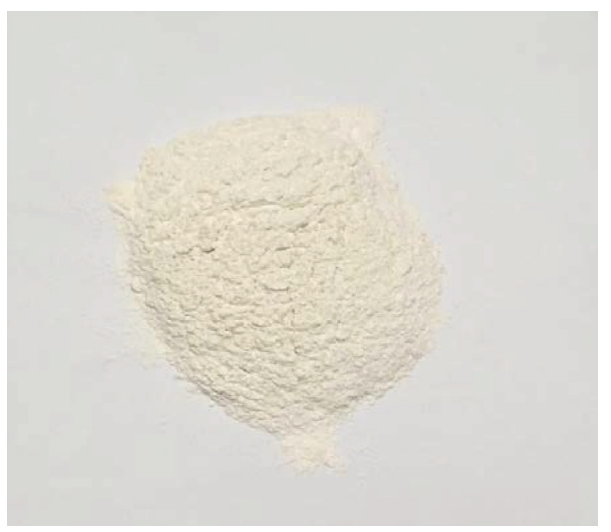

(a)

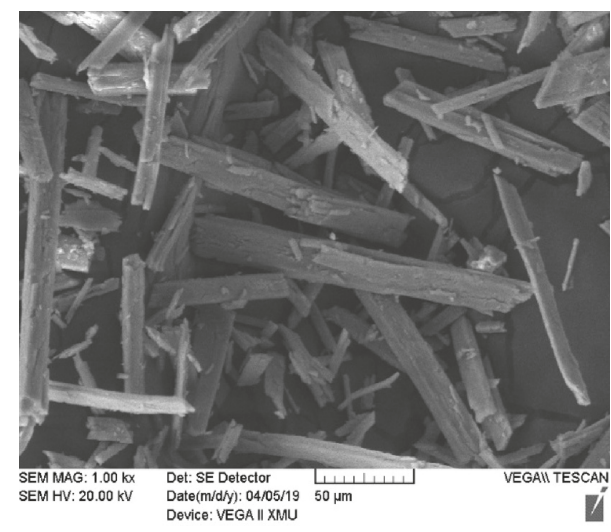

(b)

Figure 1: (a) Macroscopic and (b) microscopic images of $\mathrm{CaCO}_{3}$ whisker.

TABLE 1: Chemical compositions of raw materials (wt.\%).

\begin{tabular}{lcccccccrrr}
\hline Oxides & $\mathrm{CaO}$ & $\mathrm{SiO}_{2}$ & $\mathrm{Al}_{2} \mathrm{O}_{3}$ & $\mathrm{Fe}_{2} \mathrm{O}_{3}$ & $\mathrm{MgO}$ & $\mathrm{SO}_{3}$ & $\mathrm{CO}_{2}$ & $\mathrm{Na}_{2} \mathrm{O}$ & $\mathrm{K}_{2} \mathrm{O}$ & $\mathrm{LOI}$ \\
\hline Cement & 59.42 & 19.93 & 4.88 & 4.31 & 2.02 & 2.80 & - & 1.14 & 0.82 \\
Fly ash & 4.86 & 61.43 & 22.60 & 5.45 & 1.04 & 0.16 & - & 0.72 & 1.23 & 2.58 \\
Whisker & 54.93 & 0.29 & 0.11 & 0.07 & 2.14 & 0.31 & 42.07 & - & - \\
\hline
\end{tabular}

TABLE 2: Mix proportions of mortars.

\begin{tabular}{|c|c|c|c|c|c|c|c|c|}
\hline Set & $\begin{array}{c}\text { Mix } \\
\text { proportions }\end{array}$ & $W / b$ & Cement $\left(\mathrm{kg} / \mathrm{m}^{3}\right)$ & $\begin{array}{c}\mathrm{CaCO}_{3} \\
\text { whisker }\left(\mathrm{kg} / \mathrm{m}^{3}\right)\end{array}$ & Fly ash $\left(\mathrm{kg} / \mathrm{m}^{3}\right)$ & Sand $\left(\mathrm{kg} / \mathrm{m}^{3}\right)$ & Water $\left(\mathrm{kg} / \mathrm{m}^{3}\right)$ & Superplasticizer $\left(\mathrm{L} / \mathrm{m}^{3}\right)$ \\
\hline \multirow{5}{*}{1} & C0 (control) & 0.4 & 500 & 0 & 0 & 1375 & 200 & 0.37 \\
\hline & $\mathrm{C} 5$ & 0.4 & 475 & 25 & 0 & 1375 & 200 & 0.43 \\
\hline & $\mathrm{C} 10$ & 0.4 & 450 & 50 & 0 & 1375 & 200 & 0.47 \\
\hline & C15 & 0.4 & 425 & 75 & 0 & 1375 & 200 & 0.54 \\
\hline & $\mathrm{C} 20$ & 0.4 & 400 & 100 & 0 & 1375 & 200 & 0.59 \\
\hline \multirow{5}{*}{2} & $\mathrm{COF} 30$ & 0.4 & 350 & 0 & 150 & 1375 & 200 & 0.23 \\
\hline & C5F30 & 0.4 & 325 & 25 & 150 & 1375 & 200 & 0.25 \\
\hline & $\mathrm{C} 10 \mathrm{~F} 30$ & 0.4 & 300 & 50 & 150 & 1375 & 200 & 0.28 \\
\hline & C15F30 & 0.4 & 275 & 75 & 150 & 1375 & 200 & 0.31 \\
\hline & C20F30 & 0.4 & 250 & 100 & 150 & 1375 & 200 & 0.39 \\
\hline
\end{tabular}

Note: $\mathrm{C}$ and $\mathrm{F}$ represent $\mathrm{CaCO}_{3}$ whisker and fly ash, respectively.

thermal stability of its components. As a result, the mass variation is a direct index of the deterioration of the material after exposure to high temperature. Previous investigations have indicated that the mass loss of the cementitious material after exposure to high temperatures is mainly due to the evaporation of physically bounded water $\left(80-150^{\circ} \mathrm{C}\right)$, the dehydration of C-S-H, AFm, and AFt $\left(\leq 350^{\circ} \mathrm{C}\right)$, the decomposition of $\mathrm{CH}\left(400-550^{\circ} \mathrm{C}\right)$, and the decarbonation of $\mathrm{CaCO}_{3}\left(\geq 600^{\circ} \mathrm{C}\right)$ [35]. The mass loss of $\mathrm{CaCO}_{3}$ whiskerbased specimens is presented in Figure 2, and it is discovered that the mass loss for all the specimens regardless of without or with fly ash exhibited an upward trend with the increase in maximum temperature.

With respect to $\mathrm{CaCO}_{3}$ whisker-based mortar specimens, as shown in Figure 2(a), the mass loss increased with the increase in temperature, and for all the specimens, the mass loss reached the maximum at $1000^{\circ} \mathrm{C}$. It is interesting to notice that, before $600^{\circ} \mathrm{C}$, the mass loss between different types of specimens after exposure to a specific temperature was not obvious, while between 600 and $1000^{\circ} \mathrm{C}$, the mass loss increased with the increase in $\mathrm{CaCO}_{3}$ whisker content. This phenomenon is mainly attributed to the high thermal stable temperature of $\mathrm{CaCO}_{3}$ whisker of about $800^{\circ} \mathrm{C}$; therefore, when the temperature is lower than $600^{\circ} \mathrm{C}$, the decomposition of $\mathrm{CaCO}_{3}$ whisker will not take place, while when the temperature is in the range of $600-1000^{\circ} \mathrm{C}$, the mass loss is mainly due to the decomposition of $\mathrm{CaCO}_{3}$ whisker, and the more the $\mathrm{CaCO}_{3}$ whisker, the higher the mass loss.

Regarding $\mathrm{CaCO}_{3}$ whisker-based fly ash specimens, as shown in Figure 2(b), the mass loss of them was slightly higher than that of corresponding specimens without fly ash, regardless of the variation in high temperatures. One possible reason may be that the moderate incorporation of fly ash into the cement mortar can improve the water-retaining property of cement mortar [36]. However, the mass loss of 


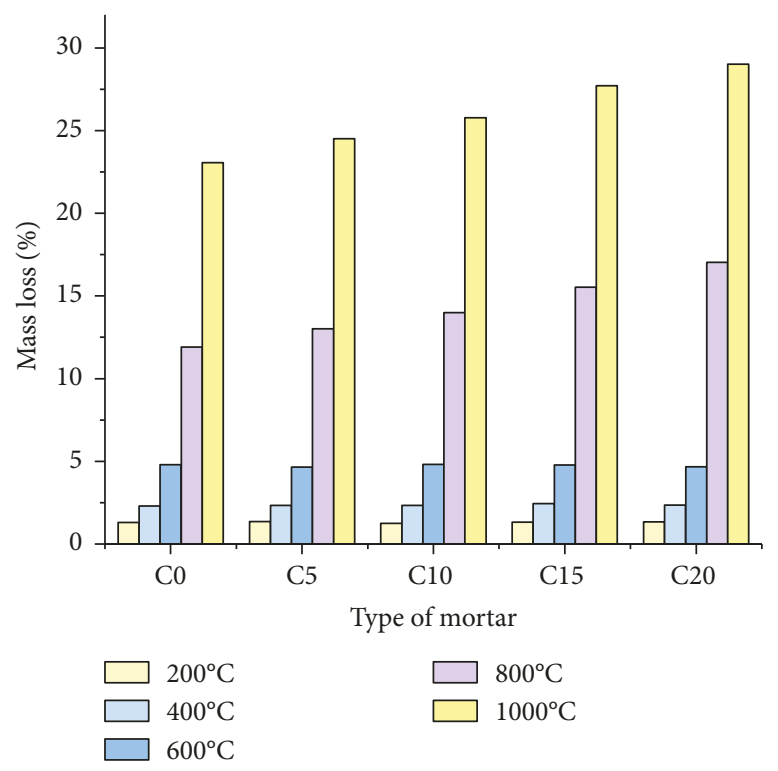

(a)

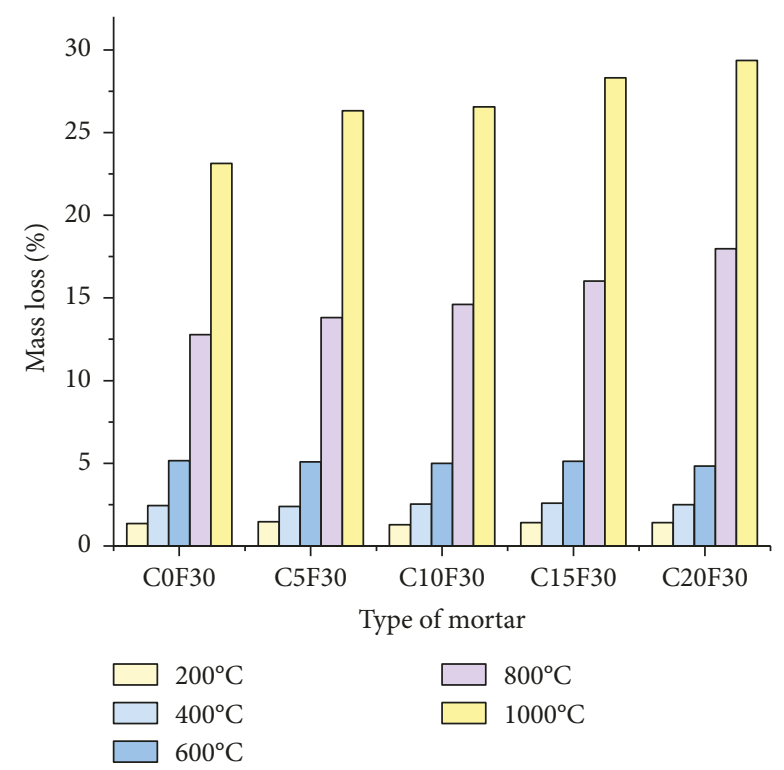

(b)

Figure 2: Mass loss of (a) $\mathrm{CaCO}_{3}$ whisker-based specimens and (b) $\mathrm{CaCO}_{3}$ whisker-based fly ash specimens after exposure to various temperatures.

specimens after being subjected to high temperature is mainly due to the evaporation of moisture; as a result, the presence of fly ash could lead to an increase in mass loss.

In general, exposure to high temperature will lead to the moisture loss of the mortar specimen which is mainly due to the evaporation of bound water and the dehydration of hydration products, and the mass loss increased with the increase in temperature. In addition, a larger $\mathrm{CaCO}_{3}$ whisker content could lead to a higher mass loss when the temperature was between 600 and $1000^{\circ} \mathrm{C}$.

3.2. Mechanical Properties. After measuring the mass of $\mathrm{CaCO}_{3}$ whisker-based specimens before and after exposure to high temperatures, the mechanical properties of those specimens were immediately evaluated. The compressive strength and flexural strength of $\mathrm{CaCO}_{3}$ whisker-based specimens are displayed in Figures 3 and 4, respectively. It is noticed that, although different temperatures had different effects on the mechanical strength of mortar specimens, the maximum strength was achieved when the temperature reached to $400^{\circ} \mathrm{C}$ for all the specimens.

Before exposure to high temperatures, both the compressive strength and flexural strength of $\mathrm{CaCO}_{3}$ whiskerbased specimen were improved rapidly with the increase in $\mathrm{CaCO}_{3}$ whisker content until this content was up to $10 \mathrm{wt} . \%$; thereafter, the strength enhancement was negatively correlated with the increase in $\mathrm{CaCO}_{3}$ whisker content, as shown in Figures 3(a) and 4(a). The reason why the strength decreased when the $\mathrm{CaCO}_{3}$ whisker content was over $10 \mathrm{wt} . \%$ may be related to the aggregation of $\mathrm{CaCO}_{3}$ whisker, which leads to the generation of a heterogeneous microstructure, thereby lowering the overall strength of $\mathrm{CaCO}_{3}$ whisker-based specimen [13]. In addition, the increase in $\mathrm{CaCO}_{3}$ whisker content may result in a relatively weak bond between cement paste and $\mathrm{CaCO}_{3}$ whisker, and thus reducing the strength of $\mathrm{CaCO}_{3}$ whisker-based specimen. Numerous studies have demonstrated that there is a critical fiber content for whisker-reinforced composites and a higher content of whisker leads to a lower strength [14-16]. Similar trend was observed in the strength of the $\mathrm{CaCO}_{3}$ whiskerbased fly ash specimen. However, a slight reduction was found in the strength of $\mathrm{CaCO}_{3}$ whisker-based specimen when $30 \mathrm{wt} . \%$ fly ash was used as partial replacement of cement, as shown in Figures 3(b) and 4(b). Take C0 and C0F30 for example, with the incorporation of fly ash, the $28 \mathrm{~d}$ strength of C0 decreased by $3.9 \%$ and $4.6 \%$ for compressive strength and flexural strength, respectively. This is because that the reduction in cement content will result in less production of hydration products, such as C-S-H which is the most important contributor to the strength of cement paste. Besides, the pozzolanic reaction of fly ash is a slow process which is only beneficial to the long-term strength development of cement paste; as a consequence, the $28 \mathrm{~d}$ strength of $\mathrm{CaCO}_{3}$ whisker-based specimens exhibited a slight decline with the incorporation of fly ash [37].

After exposure to $200^{\circ} \mathrm{C}$, the compressive strength of $\mathrm{CaCO}_{3}$ whisker-based specimen was approximately the same with the strength at $20^{\circ} \mathrm{C}$, while for $\mathrm{CaCO}_{3}$ whiskerbased fly ash specimen, the compressive strength showed a slight increase. Furthermore, an evident improvement was observed in the compressive strength of all the specimens when exposed to $400^{\circ} \mathrm{C}$, and $\mathrm{C} 10 \mathrm{~F} 30$ had the highest compressive strength at $400^{\circ} \mathrm{C}$, with the strength increased by $23.8 \%$ compared with the unheated C10F30. Relatively lower improvements were found in the compressive strength of $\mathrm{C} 0$ and $\mathrm{C} 10$ at $400^{\circ} \mathrm{C}$, which were $16.2 \%$ and $18.4 \%$, respectively, indicating that the presence of fly ash had a positive effect on the compressive strength of $\mathrm{CaCO}_{3}$ whisker-based specimens. The improvement in strength is 


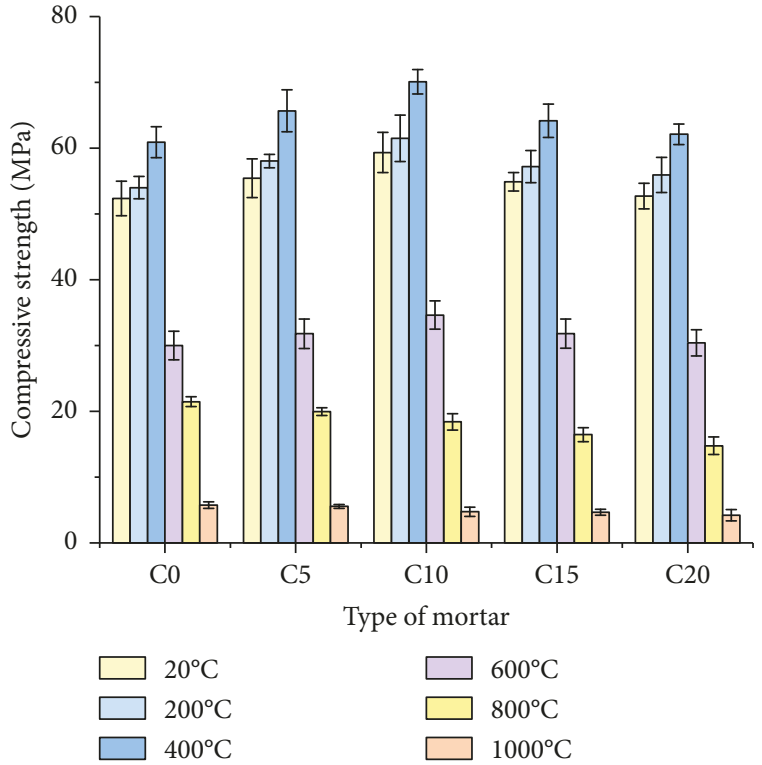

(a)

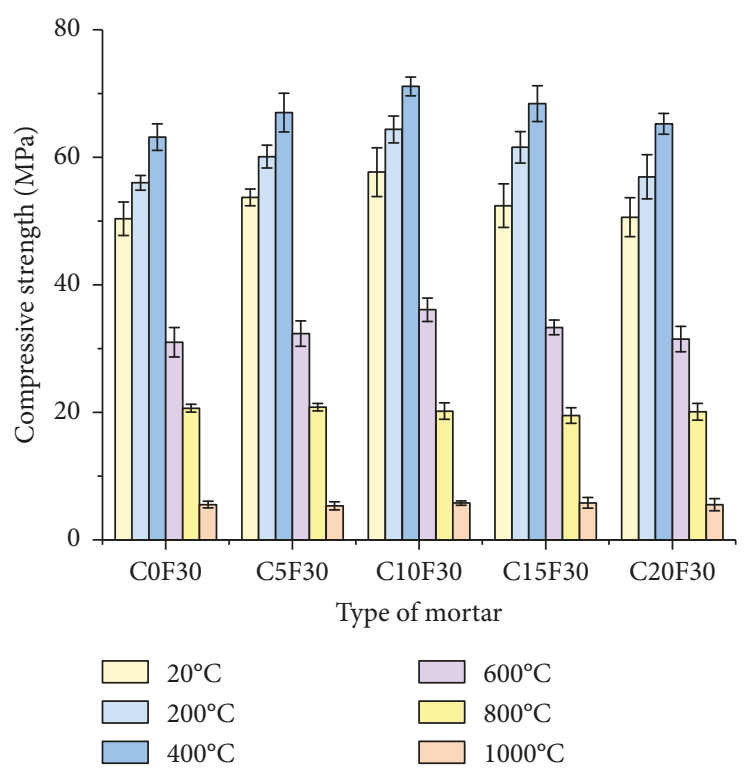

(b)

Figure 3: Compressive strength of (a) $\mathrm{CaCO}_{3}$ whisker-based specimens and (b) $\mathrm{CaCO}_{3}$ whisker-based fly ash specimens before and after exposure to various temperatures.

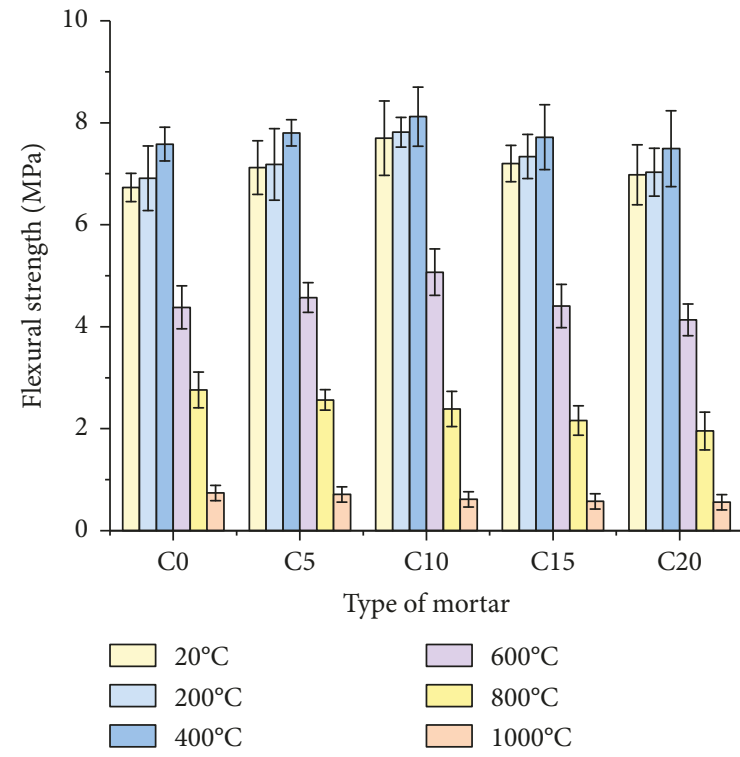

(a)

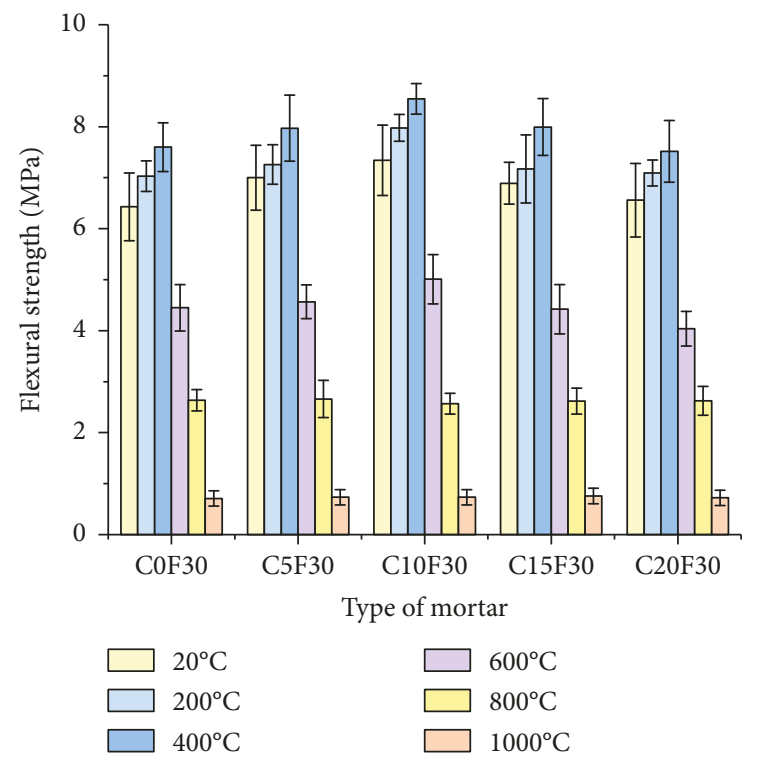

(b)

Figure 4: Flexural strength of (a) $\mathrm{CaCO}_{3}$ whisker-based specimens and (b) $\mathrm{CaCO}_{3}$ whisker-based fly ash specimens before and after exposure to various temperatures.

likely due to the acceleration in cement hydration at high temperatures. Cement hydration process will proceed at a higher speed with the increase in temperature, and meanwhile, high temperature will promote more generation of high-density C-S-H which has excellent high-temperature resistance [38]. In addition, the pozzolanic reaction of fly ash will be speeded up as well, leading to the rehydration of dissociated $\mathrm{CH}$ and the formation of additional C-S-H [39]. With regards to the flexural strength, the enhancement was not obvious, and the flexural strength of C10F 30 at $400^{\circ} \mathrm{C}$ increased by $15.9 \%$ compared with that of the unheated C10F30. The reason may lie in the fact that the loss of moisture increases the porosity of the mortar specimen and then cause the generation of microcracks which has an undesirable impact on the flexural strength of the specimen, while the bridge connection effect of $\mathrm{CaCO}_{3}$ whisker between microcracks partially offsets the negative effect brought about by high temperature exposure $[8,9]$. 
When the temperature further increased to $600^{\circ} \mathrm{C}$, both the compressive strength and flexural strength of $\mathrm{CaCO}_{3}$ whisker-based specimens showed a remarkable decrease, and the reason may be that the combined effect of moisture loss and decomposition of $\mathrm{CH}$ increases the porosity of the specimen and makes the microstructure of the specimen coarser and at the same time, weakens the bond between whiskers and cement paste; therefore, the strength of $\mathrm{CaCO}_{3}$ whisker-based specimens declined accordingly. It is worth noting that, although both the compressive strength and flexural strength of all the $\mathrm{CaCO}_{3}$ whisker-based specimens reduced significantly at $600^{\circ} \mathrm{C}$, the strength of fly ash specimens still had comparative advantage in hightemperature resistance, which indicated that fly ash could improve the high-temperature resistance of $\mathrm{CaCO}_{3}$ whiskerbased specimens.

Exposure to $800^{\circ} \mathrm{C}$ led to a sharp decrease in both compressive strength and flexural strength of specimens, which is mainly due to the decomposition of $\mathrm{CaCO}_{3}$ and $\mathrm{CSH}$ at about $800^{\circ} \mathrm{C}$ [37]. Therefore, the reduction in strength was more severe when more $\mathrm{CaCO}_{3}$ whisker was contained in the specimen, since the decomposition of $\mathrm{CaCO}_{3}$ whisker results in an even looser microstructure of the specimen. However, specimens with fly ash still had a higher strength than those without fly ash. Similarly, the strength of the specimen continued to degrade when the temperature increased to $1000^{\circ} \mathrm{C}$, leading to a further deterioration in strength.

To sum up, the incorporation of $\mathrm{CaCO}_{3}$ whisker could improve both compressive strength and flexural strength of mortar specimens when the temperature was less than $600^{\circ} \mathrm{C}$, and the optimal dosage of it was $10 \mathrm{wt} . \%$. At $800^{\circ} \mathrm{C}$ and $1000^{\circ} \mathrm{C}$, the strength of specimens rapidly decreased with the increase in $\mathrm{CaCO}_{3}$ whisker content; therefore, the specimens with $\mathrm{CaCO}_{3}$ whisker exhibited lower strength than $\mathrm{C} 0$. The presence of fly ash enhanced the hightemperature performance of $\mathrm{CaCO}_{3}$ whisker-based specimens before $600^{\circ} \mathrm{C}$ and limited the loss of strength after $600^{\circ} \mathrm{C}$. According to the results, the ordinary mortar (C0) and the mortar containing $10 \mathrm{wt} . \% \mathrm{CaCO}_{3}$ whisker and 30 wt.\% fly ash (C10F30) were selected to perform the loaddeflection test and the microscopic tests to explore the mechanism behind.

3.3. Load-Deflection Curve. Load-deflection curves of the ordinary mortar and the mortar containing 10 wt. $\% \mathrm{CaCO}_{3}$ whisker and $30 \mathrm{wt} . \%$ fly ash before and after exposure to different high temperatures were measured through the three-point bending test, and the results are presented in Figure 5. There are three stages in the load-deflection curve, including linear stage, nonlinear stage, and a softening stage. In the linear stage, the load increases with the increase in the deflection, representing that cracks do not extend, while in the nonlinear stage, cracks begin to propagate, and in the softening stage, the load decreases with the increase in the deflection, representing that cracks expand rapidly [40].

It is examined that the maximum load of both $\mathrm{C} 0$ and C10F30 increased with the increase in temperature until a maximal value was reached at $400^{\circ} \mathrm{C}$, while the maximum load of the two specimens dropped rapidly after being exposed to $600-1000^{\circ} \mathrm{C}$. Although the maximum load of the two specimens decreased at $600^{\circ} \mathrm{C}$, the maximum load of C10F30 was still higher than that of $\mathrm{C} 0$, which is mainly due to the fact that $\mathrm{CaCO}_{3}$ whisker can not only reinforce the specimen but also bridge microcracks in the specimen. Besides, the slope of the load-deflection curve of C10F30 in the linear stage before $600^{\circ} \mathrm{C}$ was a little bigger than that of $\mathrm{C} 0$, indicating that the flexural stiffness of C10F30 was higher than that of $\mathrm{C} 0$. Meanwhile, it is also worthy to note that the maximum deflection of $\mathrm{C} 10 \mathrm{~F} 30$ was a little larger than that of $\mathrm{C} 0$ before $600^{\circ} \mathrm{C}$, demonstrating that the addition of $\mathrm{CaCO}_{3}$ whisker and fly ash could improve the deformability and toughness of the specimen. This may be attributed to the fact that $\mathrm{CaCO}_{3}$ whisker itself has high tensile strength, and the incorporation of $\mathrm{CaCO}_{3}$ whisker can improve the flexural behavior of the specimen. Nevertheless, the improvement in flexural toughness was not remarkable, which can be attributed to the tiny size of whiskers, and this may be the reason to encourage the combined use of $\mathrm{CaCO}_{3}$ whiskers with other large-sized fibers, so as to improve the multiscale cracking resistance of cementitious materials.

The significant decline in the maximum load of $\mathrm{C} 10 \mathrm{~F} 30$ and $\mathrm{C} 0$ at $800^{\circ} \mathrm{C}$ pointed out that the decomposition of $\mathrm{CaCO}_{3}$ and $\mathrm{CSH}$ at this temperature range had a negative effect on the strength of specimens, and microstructural analysis will make an explanation about the change in mechanical performance. With regards to the slope of the load-deflection curve in the linear stage at $800^{\circ} \mathrm{C}$, it can be examined that the slope of C10F30 was almost the same with that of $\mathrm{C} 0$, suggesting that the two specimens had the same flexural stiffness after exposure to $800^{\circ} \mathrm{C}$. The reason may be that the addition of fly ash can enable the generation of high-density CSH which is hightemperature resistant since the decomposition of $\mathrm{CaCO}_{3}$ takes place at this temperature. Similarly, the flexural stiffness of the two specimens at $1000^{\circ} \mathrm{C}$ experienced a further decline.

3.4. Pore Size Distribution. The pore size distribution of the ordinary mortar and the mortar containing $10 \mathrm{wt} . \% \mathrm{CaCO}_{3}$ whisker and $30 \mathrm{wt} . \%$ fly ash before and after exposure to different high temperatures were obtained through utilizing MIP method, as presented in Figure 6. It is found from the results that, before exposure to high temperatures, the porosity of $\mathrm{C} 10 \mathrm{~F} 30$ showed a slight increase in comparison with $\mathrm{C} 0$. This may be linked to the fact that the addition of $\mathrm{CaCO}_{3}$ whisker may result in some additional pores in the interface between mortar matrix and whiskers, thereby leading to an increase in the porosity. In addition, the anhydrous fly ash may also cause an increase in porosity. It is worthy to note that, compared with $\mathrm{C} 0$, the volume of harmless pore $(<20 \mathrm{~nm})$ and few-harm pore $(20-50 \mathrm{~nm})$ in C10F30 was higher, and meanwhile, the volume of harmful pore (50-200 nm) was lower, which may be the reason why C10F30 with a larger porosity had higher mechanical 


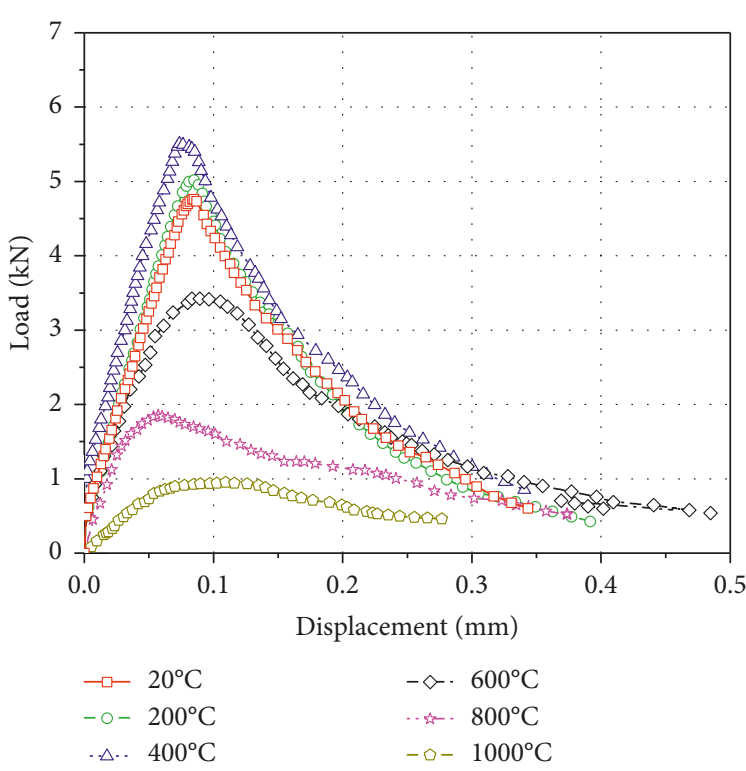

(a)

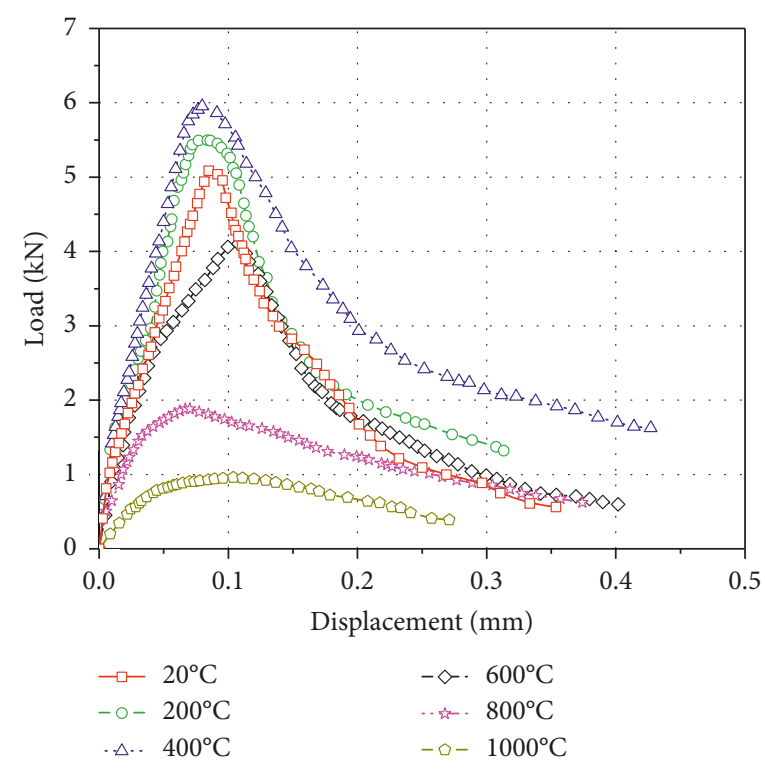

(b)

Figure 5: Load-deflection curves of (a) C0 and (b) C10F30 before and after exposure to various temperatures.

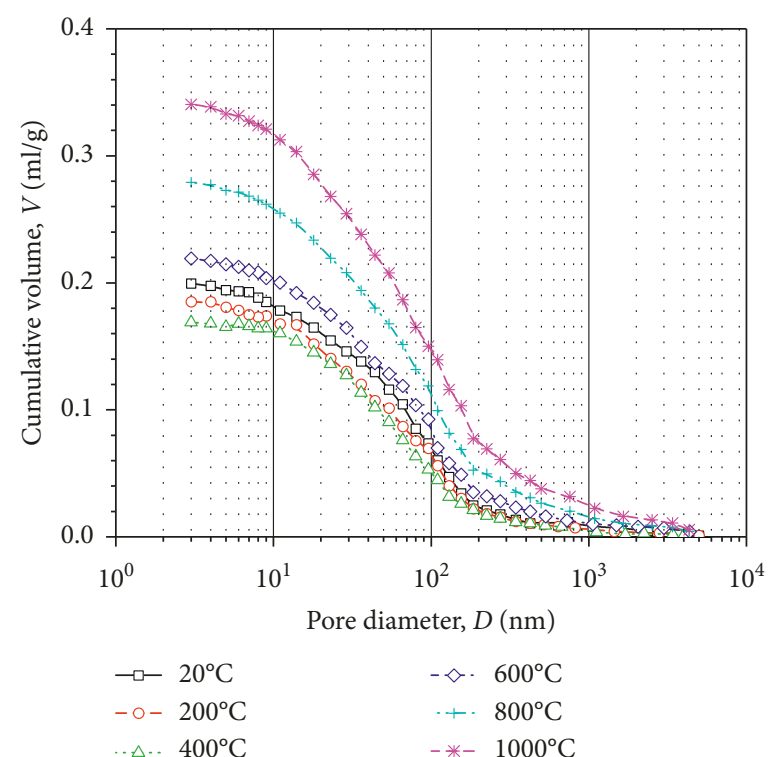

(a)

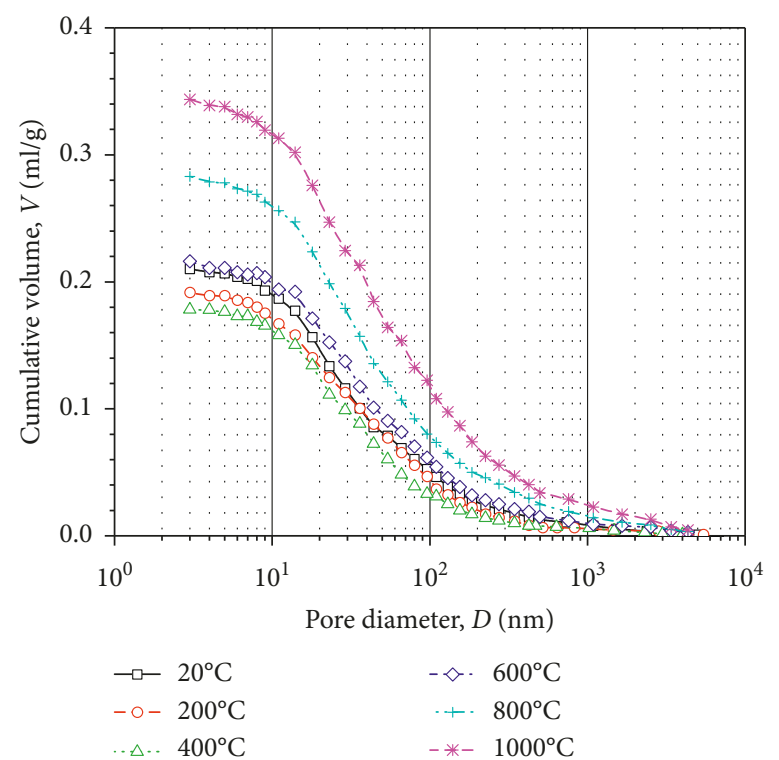

(b)

Figure 6: Pore size distribution of (a) $\mathrm{C} 0$ and (b) $\mathrm{C} 10 \mathrm{~F} 30$ before and after exposure to various temperatures.

strength compared with $\mathrm{C} 0$, for the incorporation of $\mathrm{CaCO}_{3}$ whisker and fly ash refined pore distribution in the specimen.

When exposed to $200^{\circ} \mathrm{C}, \mathrm{C} 0$ kept approximately the same porosity compared with the specimen unheated, while the porosity of $\mathrm{C} 10 \mathrm{~F} 30$ experienced a slight reduction. This phenomenon can be attributed to the fact that the increase in temperature had a positive influence on the rehydration of cement, and the pozzolanic reaction of fly ash was also stimulated by the high temperature, which enables $\mathrm{CH}$ to react with the main components of fly ash, such as $\mathrm{SiO}_{2}$ and $\mathrm{Al}_{2} \mathrm{O}_{3}$, to form C-S-H and C-A-H. Therefore, the overall porosity of the specimens showed a decrease.

Similarly, the porosity of both $\mathrm{C} 0$ and C10F30 showed a further reduction after exposure to $400^{\circ} \mathrm{C}$. High temperature may induce the generation of a large number of microcracks due to different thermal expansion coefficients of hydration products, while the presence of microfibrous $\mathrm{CaCO}_{3}$ whisker may bridge these cracks, thus refining the pore size 


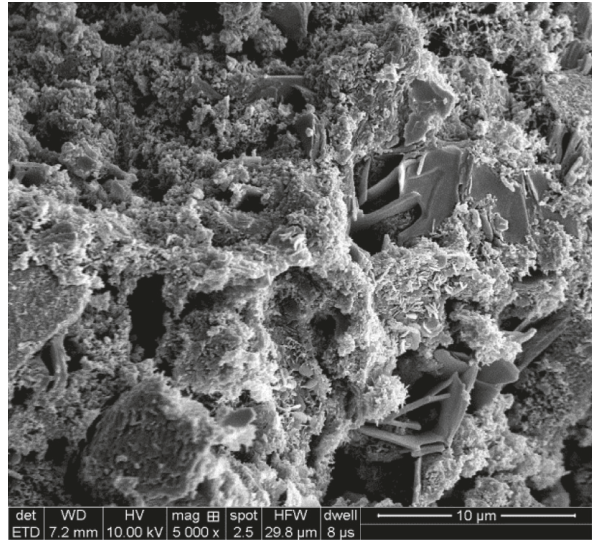

(a)

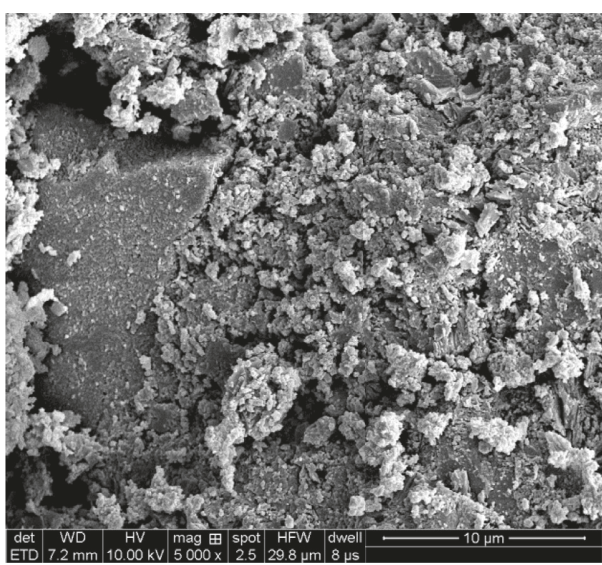

(c)

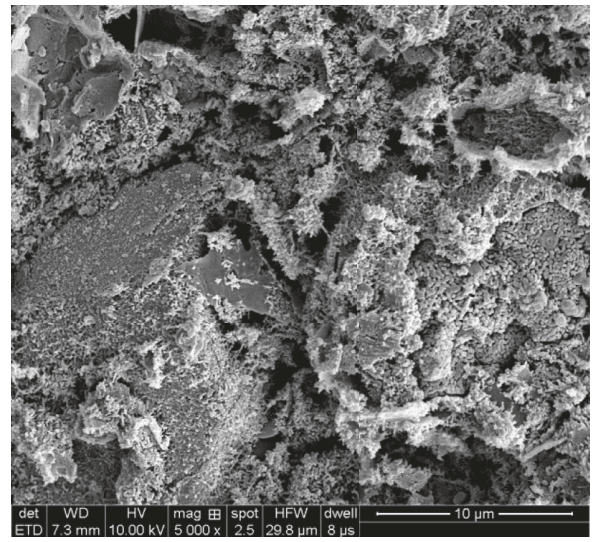

(e)

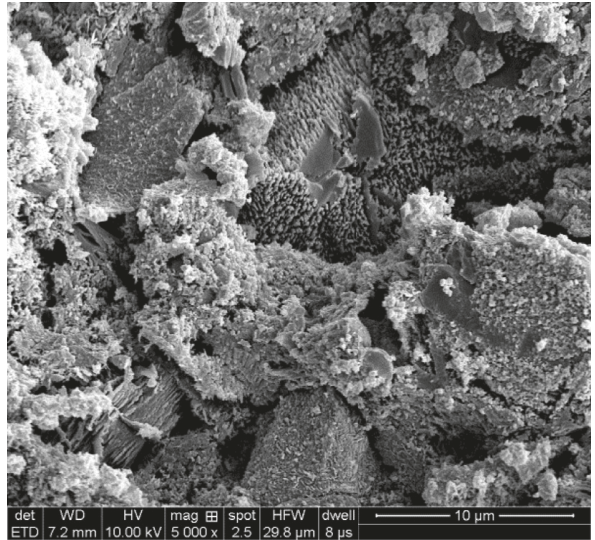

(b)

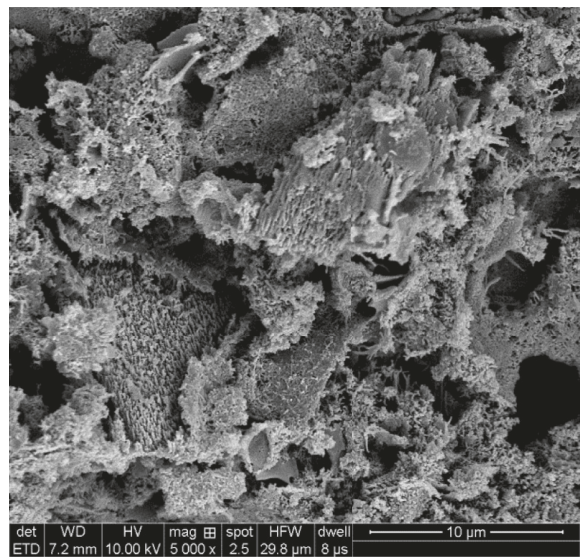

(d)

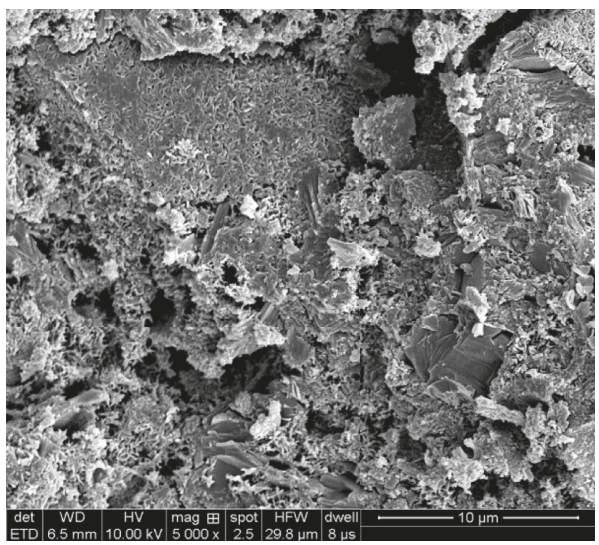

(f)

Figure 7: Microscopic images of C0 before and after exposure to different temperatures: (a) $20^{\circ} \mathrm{C}$, (b) $200^{\circ} \mathrm{C}$, (c) $400^{\circ} \mathrm{C}$, (d) $600^{\circ} \mathrm{C}$, (e) $800^{\circ} \mathrm{C}$, and (f) $1000^{\circ} \mathrm{C}$

distribution and enhance the toughness of the specimen. Furthermore, the filler effect of $\mathrm{CaCO}_{3}$ whisker can also densify the microstructure of the mortar due to the good compatibility between them. This may be the reason why C10F30 exhibited a superior high-temperature resistance in terms of mechanical strength compared with $\mathrm{C} 0$, since the mechanical strength of the specimen is closely linked with its porosity and pore size distribution.
The overall porosity of both $\mathrm{C} 0$ and C10F30 increased after being subjected to $600^{\circ} \mathrm{C}$, with the reduction in volume of harmless pores and the increase in volume of harmful pores. The decomposition of $\mathrm{CH}$, together with loss of moisture in this temperature range, increased the porosity of the two specimens, and the reason why C10F30 still maintain the superior mechanical strength compared with $\mathrm{C} 0$ is most likely due to the combined effect of $\mathrm{CaCO}_{3}$ 


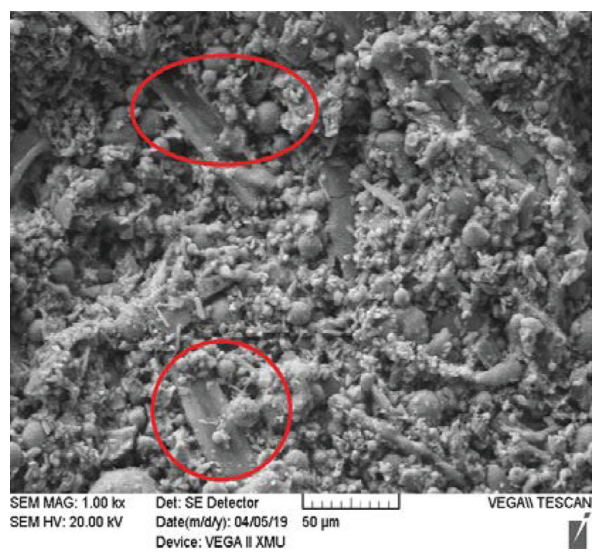

(a)

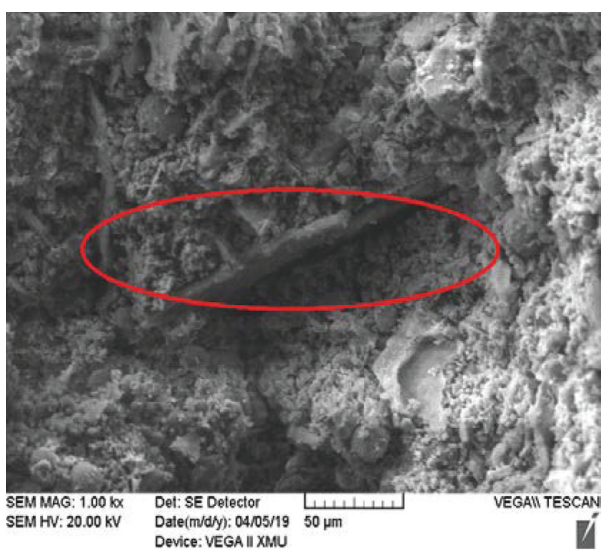

(c)

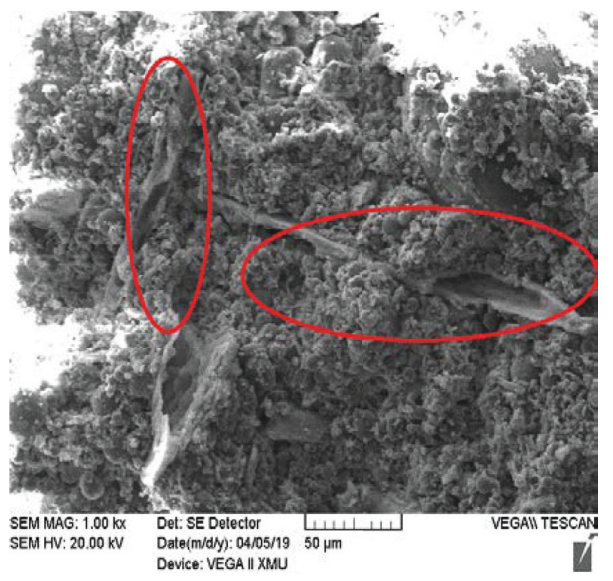

(e)

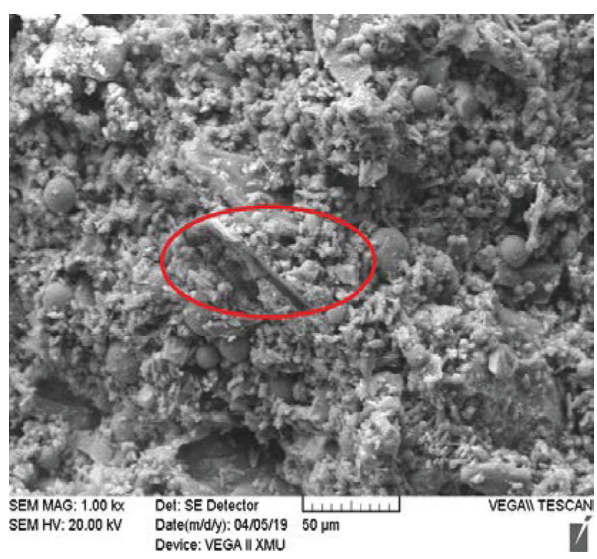

(b)

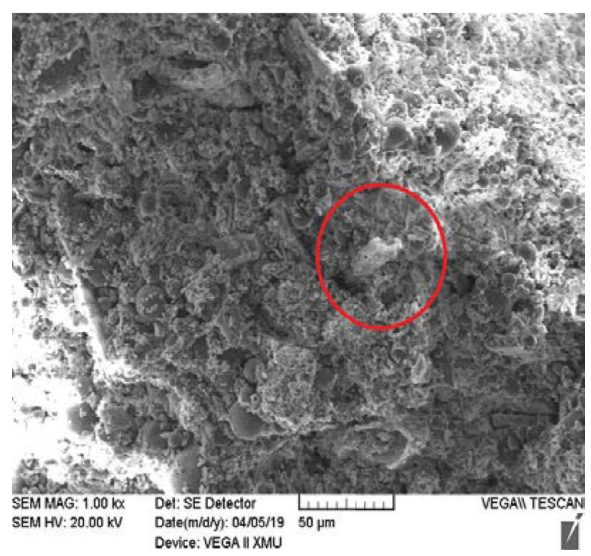

(d)

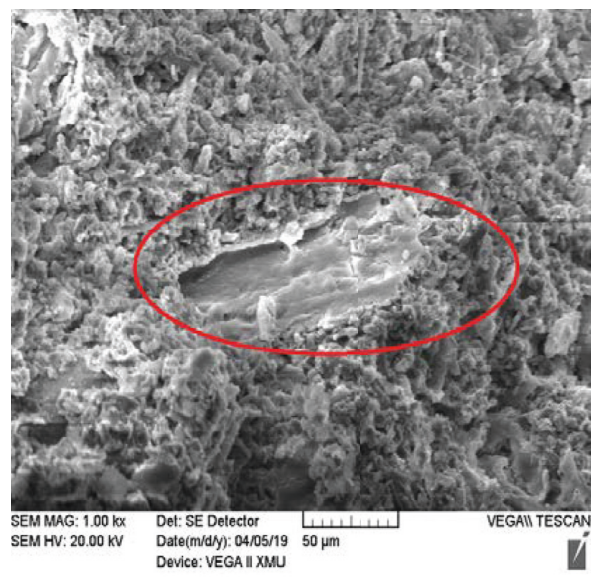

(f)

FIGURE 8: Microscopic images of $\mathrm{C} 10 \mathrm{~F} 30$ before and after exposure to different temperatures $\left(\mathrm{CaCO}_{3}\right.$ whiskers are marked in the red circle): (a) $20^{\circ} \mathrm{C}$, (b) $200^{\circ} \mathrm{C}$, (c) $400^{\circ} \mathrm{C}$, (d) $600^{\circ} \mathrm{C}$, (e) $800^{\circ} \mathrm{C}$, and (f) $1000^{\circ} \mathrm{C}$.

whisker to bridge the microcracks and fly ash to proceed the pozzolanic reaction with $\mathrm{CH}$ and free lime [41].

The porosity of $\mathrm{C} 10 \mathrm{~F} 30$ and $\mathrm{C} 0$ increased dramatically after exposure to $800^{\circ} \mathrm{C}$ and $1000^{\circ} \mathrm{C}$, because more hydration products, such as $\mathrm{CaCO}_{3}$ and $\mathrm{CSH}$, will be disintegrated, resulting in a much coarser microstructure of the specimen. Meanwhile, although $\mathrm{CaCO}_{3}$ whisker decomposed in this temperature range, the porosity of $\mathrm{C} 10 \mathrm{~F} 30$ was almost equal to $\mathrm{C}$, the reason may be that fly ash enables the generation of thermostable hydration products [41].

3.5. SEM Analysis. Microscopic images of the ordinary mortar and the mortar containing 10 wt. $\% \mathrm{CaCO}_{3}$ whisker and $30 \mathrm{wt} . \%$ fly ash before and after exposure to different high temperatures are presented in Figures 7 and 8. The scale 
for Figure 7 is $10 \mu \mathrm{m}$, while Figure 8 has a scale of $50 \mu \mathrm{m}$ in order to examine the behavior of $\mathrm{CaCO}_{3}$ whisker better.

The microstructural images of $\mathrm{C} 0$ before and after exposure to high temperatures of $200^{\circ} \mathrm{C}, 400^{\circ} \mathrm{C}, 600^{\circ} \mathrm{C}, 800^{\circ} \mathrm{C}$, and $1000^{\circ} \mathrm{C}$ are shown in Figure 7. As seen in Figure 7(a), hydration products such as $\mathrm{CH}$ and $\mathrm{C}-\mathrm{S}-\mathrm{H}$ were distributed in $\mathrm{C} 0$, and the microstructure of $\mathrm{C} 0$ was not very dense. However, after exposure to $200^{\circ} \mathrm{C}$, more $\mathrm{C}-\mathrm{S}$ - $\mathrm{H}$ was generated due to the further hydration of cement, and the similar trend was discovered in Figure 7 (c) when $\mathrm{C} 0$ was heated to $400^{\circ} \mathrm{C}$. After exposure to $600^{\circ} \mathrm{C}$, the microstructure of $\mathrm{C} 0$ became coarser, and microcracks were found in the specimen. The even looser microstructures after $800^{\circ} \mathrm{C}$ and $1000^{\circ} \mathrm{C}$ in Figures $7(\mathrm{e})$ and $7(\mathrm{f})$ represented the deterioration of the specimen under high temperature, which was in agreement with the results of mechanical strength tests and porosity test.

Figure 8 shows microstructural images of C10F30 before and after exposure to high temperatures of $200^{\circ} \mathrm{C}, 400^{\circ} \mathrm{C}$, $600^{\circ} \mathrm{C}, 800^{\circ} \mathrm{C}$, and $1000^{\circ} \mathrm{C}$. It can be seen from Figure $8(\mathrm{a})$ that spherical fly ash particles and $\mathrm{CaCO}_{3}$ whiskers were uniformly distributed in the specimen, demonstrating that the pozzolanic reaction of fly ash is a slow process, and there is still much unreacted fly ash at $28 \mathrm{~d}$ of curing. When C10F30 was subjected to high temperature of $200^{\circ} \mathrm{C}$, the microstructure of the specimen became denser which was proved by the improvement in mechanical strength. The morphology of $\mathrm{C} 10 \mathrm{~F} 30$ after exposure to $400^{\circ} \mathrm{C}$ indicated that the further reaction of fly ash made the microstructure of C10F30 become even more compact, with fewer unreacted fly ash particles left in the specimen. Besides, microcracks were observed in the specimen and the presence of $\mathrm{CaCO}_{3}$ whiskers restrained the propagation of these microcracks, as shown in Figure 8(c). Therefore, the strength of C10F30 after being subjected to $400^{\circ} \mathrm{C}$ was higher with the incorporation of $\mathrm{CaCO}_{3}$ whisker and fly ash. After exposure to $600^{\circ} \mathrm{C}, \mathrm{C} 10 \mathrm{~F} 30$ exhibited a porous and coarse microstructure due to the decomposition of $\mathrm{CH}$ and further moisture loss, while the $\mathrm{CaCO}_{3}$ whisker pullout, as presented in Figure 8(d), demonstrated the reinforcing effect of $\mathrm{CaCO}_{3}$ whisker on the mechanical properties of the specimen. With the increasing temperature to $800^{\circ} \mathrm{C}, \mathrm{CaCO}_{3}$ whisker was almost disintegrated, as shown in Figure 8(e), with the thin shell of whiskers left in the specimen. And at $1000^{\circ} \mathrm{C}, \mathrm{CaCO}_{3}$ whiskers were totally disintegrated, and the changes in microstructures agreed with the variations in mechanical strength. It can also be found that $\mathrm{C} 10 \mathrm{~F} 30$ had a relatively compact microstructure than $\mathrm{C} 0$ when the temperature exceeded $600^{\circ} \mathrm{C}$.

\section{Conclusion}

The objective of the current study is to investigate the combined effect of $\mathrm{CaCO}_{3}$ whisker and fly ash on cement mortars before and after exposure to varying high temperatures and evaluate the high-temperature resistance of different types of mortars. Conclusions drawn from the experimental results were listed as follows:

(1) High-temperature exposure caused the increase in mass loss for all the $\mathrm{CaCO}_{3}$ whisker-based mortars, regardless of without or with fly ash, and the mass loss increased with the increase in maximum temperature. $\mathrm{CaCO}_{3}$ whisker-based fly ash mortars exhibited a slight increase in mass loss in comparison with their corresponding mortars without fly ash.

(2) Before exposure to high temperatures, the mechanical strength of $\mathrm{CaCO}_{3}$ whisker-based mortars was enhanced with the increasing dosage of $\mathrm{CaCO}_{3}$ whisker, while the mechanical strength showed a downward trend when the $\mathrm{CaCO}_{3}$ whisker content was more than $10 \mathrm{wt} . \%$. The incorporation of fly ash led to a slight decrease in mechanical strength of mortars.

(3) With respect to $\mathrm{CaCO}_{3}$ whisker-based specimens, they reached their maximum strength after exposure to $400^{\circ} \mathrm{C}$, while the strength of them decreased notably when exposed to $600^{\circ} \mathrm{C}$. At $800^{\circ} \mathrm{C}$ and $1000^{\circ} \mathrm{C}$, the strength of these specimens exhibited a further decrease, and due to the decomposition of $\mathrm{CaCO}_{3}$ whisker, specimens with more $\mathrm{CaCO}_{3}$ whisker had the lower strength.

(4) With respect to $\mathrm{CaCO}_{3}$ whisker-based fly ash specimens, in spite of a slight decrease in the strength at $20^{\circ} \mathrm{C}$, the strength of them at $200^{\circ} \mathrm{C}$ and $400^{\circ} \mathrm{C}$ was even higher than that of corresponding specimens without fly ash. And after exposure to $600^{\circ} \mathrm{C}$, the residual strength was still higher, indicating that the high-temperature resistance of $\mathrm{CaCO}_{3}$ whiskerbased mortar was improved due to the presence of fly ash. Although the decomposition of $\mathrm{CaCO}_{3}$ whisker took place at $800^{\circ} \mathrm{C}$ and $1000^{\circ} \mathrm{C}$, the strength of fly ash specimens was almost the same with $\mathrm{C} 0$.

(5) Compared with C0, C10F30 exhibited superior mechanical properties after exposure to different temperatures.

(6) With the incorporation of $\mathrm{CaCO}_{3}$ whisker and fly ash, the flexural stiffness and flexural toughness of the specimen were improved before $600^{\circ} \mathrm{C}$.

(7) Although the total porosity of $\mathrm{C} 10 \mathrm{~F} 30$ at $20^{\circ} \mathrm{C}$ increased, the overall pore distribution was refined compared with $\mathrm{C} 0$. There was an evident decline in pore volume of mortars when exposed to $400^{\circ} \mathrm{C}$, but exposure to temperatures higher than $600^{\circ} \mathrm{C}$ resulted in a significant increase in pore volume.

(8) Microscopic images showed that the filler effect and crack-bridging effect of $\mathrm{CaCO}_{3}$ whisker, together with the acceleration in pozzolanic reaction of fly ash at high temperatures, made $\mathrm{C} 10 \mathrm{~F} 30$ possess preferable high-temperature resistance capacity, which could be reflected in the results of mechanical tests.

\section{Data Availability}

The data used to support the findings of this study are available from the corresponding author upon request.

\section{Conflicts of Interest}

The authors declare that they have no conflicts of interest. 


\section{Acknowledgments}

This research was sponsored by the Fundamental Research Funds for the Central Universities of Chang'an University (no. 300102218523), First-Class Discipline and First-Class Professional Construction of Chang'an University (no. 0021/ 300203110004), and the Outstanding Doctoral Dissertation Cultivation Subsidy Project of Chang'an University (no. 300102219715). The authors acknowledged the support.

\section{References}

[1] H. Tanyildizi and A. Coskun, "The effect of high temperature on compressive strength and splitting tensile strength of structural lightweight concrete containing fly ash," Construction and Building Materials, vol. 22, no. 11, pp. 22692275, 2008.

[2] O. Düğenci, T. Haktanir, and F. Altun, "Experimental research for the effect of high temperature on the mechanical properties of steel fiber-reinforced concrete," Construction and Building Materials, vol. 75, pp. 82-88, 2015.

[3] H. Tanyildizi and Y. Yonar, "Mechanical properties of geopolymer concrete containing polyvinyl alcohol fiber exposed to high temperature," Construction and Building Materials, vol. 126, pp. 381-387, 2016.

[4] M. Rangelov, S. Nassiri, L. Haselbach, and K. Englund, "Using carbon fiber composites for reinforcing pervious concrete," Construction and Building Materials, vol. 126, pp. 875-885, 2016.

[5] S. Nasir, M. Ayoub, S. Zafar et al., "Experimental study on comparison of strength properties of natural waste fiber (Coir and Jute) reinforced concrete," Journal of Applied and Emerging Sciences, vol. 7, pp. 105-110, 2018.

[6] Y. Wang, X. Cao, L. Zhang et al., "Effects of cellulose whiskers on properties of soy protein thermoplastics," Macromolecular Bioscience, vol. 6, no. 7, pp. 524-531, 2006.

[7] J. Bras, M. L. Hassan, C. Bruzesse, E. A. Hassan, N. A. ElWakil, and A. Dufresne, "Mechanical, barrier, and biodegradability properties of bagasse cellulose whiskers reinforced natural rubber nanocomposites," Industrial Crops and Products, vol. 32, no. 3, pp. 627-633, 2010.

[8] M. Cao, X. Ming, H. Yin, and L. Li, "Influence of high temperature on strength, ultrasonic velocity and mass loss of calcium carbonate whisker reinforced cement paste," Composites Part B: Engineering, vol. 163, pp. 438-446, 2019.

[9] M. Cao, L. Li, H. Yin, and X. Ming, "Microstructure and strength of calcium carbonate $\left(\mathrm{CaCO}_{3}\right)$ whisker reinforced cement paste after exposed to high temperatures," Fire Technology, 2019.

[10] M. Cao, C. Zhang, H. Lv, and L. Xu, "Characterization of mechanical behavior and mechanism of calcium carbonate whisker-reinforced cement mortar," Construction and Building Materials, vol. 66, pp. 89-97, 2014.

[11] M. Cao, L. Xu, C. Zhang et al., "Rheology, fiber distribution and mechanical properties of calcium carbonate $\left(\mathrm{CaCO}_{3}\right)$ whisker reinforced cement mortar," Composites Part A: Applied Science and Manufacturing, vol. 90, pp. 662-669, 2016.

[12] Y. Yang, S. Fu, X. Li et al., "Mechanical attributes of uniaxial compression for calcium carbonate whisker reinforced oil well cement pastes," Advances in Materials Science and Engineering, vol. 2017, Article ID 2939057, 13 pages, 2017.

[13] X. Cheng, Q. Dong, Z. Li et al., "High-temperature mechanical properties of $\mathrm{CaSO}_{4}$ whiskers reinforced high alumina cement," Magazine of Concrete Research, vol. 70, pp. 1-13, 2018.

[14] M. Li, S. Deng, Y. Yu, J. Jin, Y. Yang, and X. Guo, "Mechanical properties and microstructure of oil well cement stone enhanced with Tetra-needle like $\mathrm{ZnO}$ whiskers," Construction and Building Materials, vol. 135, pp. 59-67, 2017.

[15] M. Li, M. He, Y. Yu, S. Deng, and X. Guo, "Mechanical properties and microstructure of oil-well cement stone enhanced with submicron SiC whiskers," Journal of Adhesion Science and Technology, vol. 33, no. 1, pp. 50-65, 2019.

[16] X. Cheng, Q. Dong, Z. Li, X. Guo, and W. Duan, "Influence of potassium titanate whisker on the mechanical properties and microstructure of calcium aluminate cement for in situ combustion," Journal of Adhesion Science and Technology, vol. 32, no. 4, pp. 343-358, 2018.

[17] M. Li, Y. Yang, M. Liu, X. Guo, and S. Zhou, "Hybrid effect of calcium carbonate whisker and carbon fiber on the mechanical properties and microstructure of oil well cement," Construction and Building Materials, vol. 93, pp. 995-1002, 2015.

[18] M. Li, M. Liu, Y. Yang, Z. Li, and X. Guo, "Mechanical properties of oil well cement stone reinforced with hybrid fiber of calcium carbonate whisker and carbon fiber," $P e$ troleum Exploration and Development, vol. 42, no. 1, pp. 104-111, 2015.

[19] M. Cao, C. Zhang, Y. Li et al., "Using calcium carbonate whisker in hybrid fiber-reinforced cementitious composites," Journal of Materials in Civil Engineering, vol. 27, no. 4, article 04014139, 2014.

[20] M. Cao, L. Xu, and C. Zhang, "Rheological and mechanical properties of hybrid fiber reinforced cement mortar," Construction and Building Materials, vol. 171, pp. 736-742, 2018.

[21] Y. Yang and Y. Deng, "Mechanical properties of hybrid short fibers reinforced oil well cement by polyester fiber and calcium carbonate whisker," Construction and Building Materials, vol. 182, pp. 258-272, 2018.

[22] M. S. Imbabi, C. Carrigan, and S. McKenna, "Trends and developments in green cement and concrete technology," International Journal of Sustainable Built Environment, vol. 1, no. 2, pp. 194-216, 2012.

[23] E. Benhelal, G. Zahedi, E. Shamsaei, and A. Bahadori, "Global strategies and potentials to curb $\mathrm{CO}_{2}$ emissions in cement industry," Journal of Cleaner Production, vol. 51, pp. 142-161, 2013.

[24] R. K. Ibrahim, R. Hamid, and M. R. Taha, "Fire resistance of high-volume fly ash mortars with nanosilica addition," Construction and Building Materials, vol. 36, pp. 779-786, 2012.

[25] S. Soleimanzadeh and M. M. A. Othuman, "Influence of high temperatures on flexural strength of foamed concrete containing fly ash and polypropylene fiber," International Journal of Engineering, vol. 26, no. 2, pp. 117-126, 2013.

[26] ASTM (American Society for Testing and Materials), "C150: standard specification for Portland cement," in Annual Book of ASTM, ASTM, West Conshohocken, PA, USA, 2001.

[27] ASTM (American Society for Testing and Materials), C618: Standard Specification for Coal Fly Ash and Raw or Calcined Natural Pozzolan for Use in Concrete, ASTM, West Conshohocken, PA, USA, 2012.

[28] ASTM (American Society for Testing and Materials), C494: TYPE F: Standard Specification for Chemical Admixtures for Concrete, ASTM, West Conshohocken, PA, USA, 2001.

[29] S. Donatello, C. Kuenzel, A. Palomo, and A. FernándezJiménez, "High temperature resistance of a very high volume 
fly ash cement paste," Cement and Concrete Composites, vol. 45, pp. 234-242, 2014.

[30] ASTM (American Society for Testing and Materials), C109/ C109M-16a: Standard Test Method for Compressive Strength of Hydraulic Cement Mortars (Using 2-in. or [50-mm] Cube Specimens), ASTM, West Conshohocken, PA, USA, 2016.

[31] ASTM (American Society for Testing and Materials), C348-18: Standard Test Method for Flexural Strength of Hydraulic-Cement Mortars, ASTM, West Conshohocken, PA, USA, 2018.

[32] ASTM (American Society for Testing and Materials), C1609/ C1609M-12: Standard Test Method for Flexural Performance of Fiber-Reinforced Concrete (Using Beam with Third-Point Loading), ASTM, West Conshohocken, PA, USA, 2012.

[33] M.-H. Zhang and H. Li, "Pore structure and chloride permeability of concrete containing nano-particles for pavement," Construction and Building Materials, vol. 25, no. 2, pp. 608-616, 2011.

[34] BS ISO, Pore Size Distribution and Porosity of Solid Materials by Mercury Porosimetry and Gas Adsorption, BS ISO, 15901-1, London, UK, 2005.

[35] S. Bahafid, S. Ghabezloo, M. Duc, P. Faure, and J. Sulem, "Effect of the hydration temperature on the microstructure of Class G cement: C-S-H composition and density," Cement and Concrete Research, vol. 95, pp. 270-281, 2017.

[36] N. Khurram, K. Khan, M. U. Saleem, M. N. Amin, and U. Akmal, "Effect of elevated temperatures on mortar with naturally occurring volcanic ash and its blend with electric arc furnace slag," Advances in Materials Science and Engineering, vol. 2018, Article ID 5324036, 11 pages, 2018.

[37] A. M. Rashad, "An exploratory study on high-volume fly ash concrete incorporating silica fume subjected to thermal loads," Journal of Cleaner Production, vol. 87, pp. 735-744, 2015.

[38] M. J. DeJong and F.-J. Ulm, "The nanogranular behavior of $\mathrm{C}-\mathrm{S}-\mathrm{H}$ at elevated temperatures (up to $700^{\circ} \mathrm{C}$ ), "Cement and Concrete Research, vol. 37, no. 1, pp. 1-12, 2007.

[39] M. H. Beigi, J. Berenjian, O. Lotfi Omran, A. Sadeghi Nik, and I. M. Nikbin, "An experimental survey on combined effects of fibers and nanosilica on the mechanical, rheological, and durability properties of self-compacting concrete," Materials \& Design, vol. 50, pp. 1019-1029, 2013.

[40] S. Djaknoun, E. Ouedraogo, and A. Ahmed Benyahia, "Characterisation of the behaviour of high performance mortar subjected to high temperatures," Construction and Building Materials, vol. 28, no. 1, pp. 176-186, 2012.

[41] O. Karahan, "Transport properties of high volume fly ash or slag concrete exposed to high temperature," Construction and Building Materials, vol. 152, pp. 898-906, 2017. 


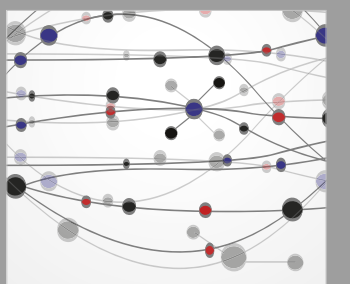

The Scientific World Journal
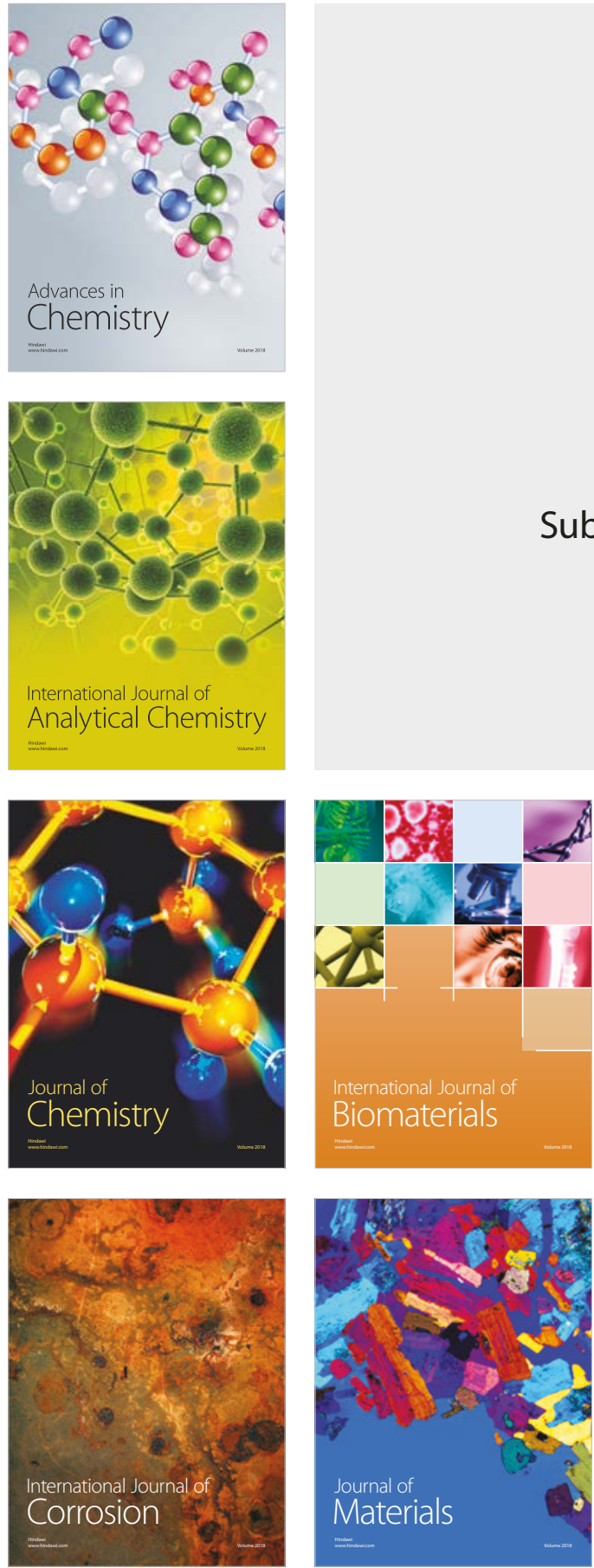

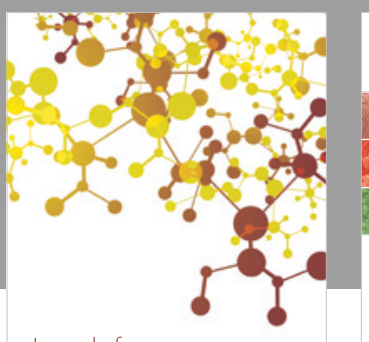

Journal of

Applied Chemistry
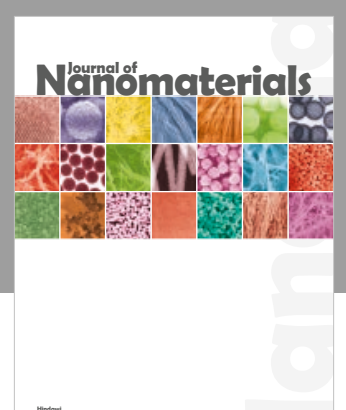

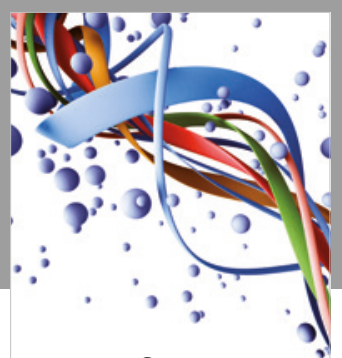

Scientifica

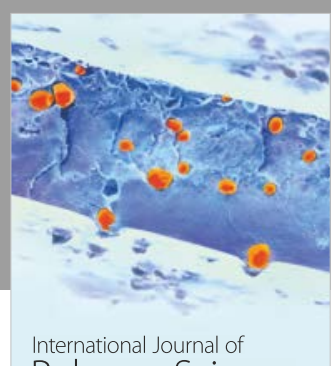

Polymer Science

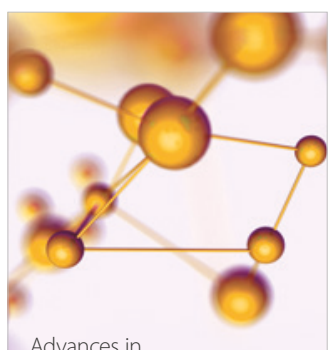

Physical Chemistry
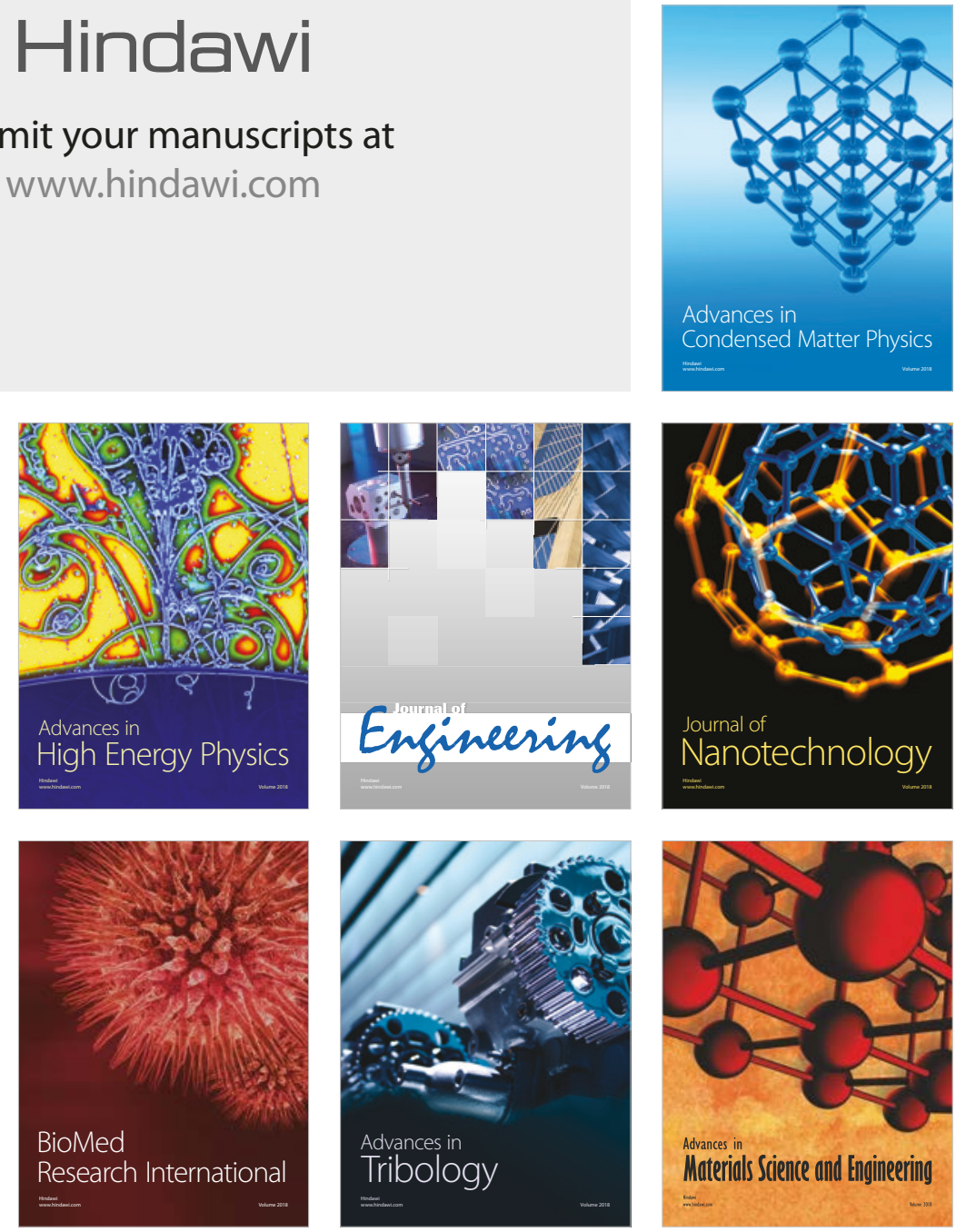